\title{
Subendocardial Fibrosis in Remote Myocardium Results from Reduction of Coronary Driving Pressure During Acute Infarction in Rats
}

\author{
Clovis de Carvalho Frimm, Marcia Kiyomi Koike, Mariana Cúri
}

São Paulo, SP - Brazil

\begin{abstract}
Objective - To investigate the role of hemodynamic changes occurring during acute MI in subsequent fibrosis deposition within non-MI.

Methods - By using the rat model of MI, 3 groups of 7 rats each [sham, SMI $(M I<30 \%)$, and LMI $(M I>30 \%)$ ] were compared. Systemic and left ventricular $(L V)$ hemodynamics were recorded 10 minutes before and after coronary artery ligature. Collagen volume fraction (CVF) was calculated in picrosirius red-stained heart tissue sections 4 weeks later.

Results - Before surgery, all hemodynamic variables were comparable among groups. After surgery, LV end-diastolic pressure increased and coronary driving pressure decreased significantly in the LMI compared with the sham group. $L V d P / d t_{\max }$ and $d P / d t_{\min }$ of both the SMI and LMI groups were statistically different from those of the sham group. CVF within non-MI interventricular septum and right ventricle did not differ between each MI group and the sham group. Otherwise, subendocardial (SE) CVF was statistically greater in the LMI group. SECVF correlated negatively with post-MI systemic blood pressure and coronary driving pressure, and positively with post-MI LV dP/dt ${ }_{\min }$. Stepwise regression analysis identified post-MI coronary driving pressure as an independent predictor of SE CVF.
\end{abstract}

Conclusion - $L V$ remodeling in rats with MI is characterized by predominant SE collagen deposition in non-MI and results from a reduction in myocardial perfusion pressure occurring early on in the setting of MI.

Key words: coronary driving pressure, subendocardial fibrosis, hemodynamic, myocardial infarction, ventricular remodeling

\footnotetext{
University of São Paulo Medical School and Institute of Mathematics and Statistics - University of São Paulo - São Paulo - Brazil.

Mailing address: Clovis de Carvalho Frimm - Faculdade de Medicina da USP, LIM 51 - Av. Dr. Arnaldo, 455 - 01246-903 - São Paulo, SP, Brasil - E-mail: frimm@emercli.fm.usp.br.

Research supported by Fundação E.J. Zerbini and LIM-51-HC/FMUSP.
}

Cardiac remodeling following myocardial infarction (MI) is characterized by scar formation with wall thinning at the site of myocyte fiber loss and progressive left ventricular (LV) dilatation with collagen deposition within noninfarcted myocardium (non-MI) ${ }^{1}$.

Ventricular dilatation is a primary consequence of MIlocation and size ${ }^{2}$, but other factors influence fibrosis accumulation, such as the cardiac renin-angiotensin system, endothelins, catecholamines, and inflammatory mediators ${ }^{3,4}$. However, the role of hemodynamic changes occurring during ongoing infarction have not been investigated ${ }^{5}$. It is still also unclear where fibrosis deposition actually takes place, because subendocardial (SE) regions of non-MI have rarely been contemplated in post-MI morphometric studies ${ }^{6,7}$.

The aim of this study was to investigate, using the experimental MI model in the rat, the role of hemodynamic changes taking place acutely after left coronary artery ligature in subsequent fibrosis accumulation within non-MI.

\section{Methods}

Twenty-one male Wistar rats weighing $275 \pm 5 \mathrm{~g}$ were used for the experiments. All procedures were carried out in accordance with the norms of the Brazilian College of Animal Experiments and conformed to the "Guide for the Care and Use of Laboratory Animals." Our Institutional Ethical Committee approved the protocol.

Animals were anesthetized with Ketamine chloride, $50 \mathrm{mg} . \mathrm{kg}^{-1}$ i.p. and Pentobarbital sodium, $25 \mathrm{mg} . \mathrm{kg}^{-1}$ i.p. and put under mechanical ventilation with a rodent ventilator (Model 683, Harvard Apparatus Inc., MA USA). Systemic and LV blood pressures were obtained from femoral and carotid arteries, respectively. The catheters were connected to pressure transducers and coupled to a calibrated preamplifier (General Purpose Amplifier 4 - model 2, Stemtech Inc. WI, USA). The pressure tracings were recorded by using a computerized system processor (AT/Codas, Dataq Instruments Inc., OH, USA). 
After hemodynamic stabilization, pressure tracings were recorded for 10 minutes before opening the chest wall and continued throughout the entire surgical procedure. The thoracic cage was closed and residual air drained from the pleural space. When new steady hemodynamic signals were observed, an additional 10-minute period of hemodynamic recording was performed. The average of beat to beat hemodynamic measures recorded during the 2 aforementioned 10-minute periods was analyzed.

Heart rate (beats. $\mathrm{min}^{-1}$ ), LV systolic pressure (LVSP, $\mathrm{mmHg}$ ), LV end-diastolic pressure (LVEDP, $\mathrm{mm} \mathrm{Hg}$ ), LV dP/ $\mathrm{dt}_{\text {max }}, \mathrm{LV} \mathrm{dP/dt} t_{\text {min }}\left(\mathrm{mm} \mathrm{Hg} . \mathrm{s}^{-1}\right)$ and systemic systolic blood pressure (SBP, $\mathrm{mmHg}$ ), and diastolic blood pressure (DBP, $\mathrm{mmHg}$ ) were recorded. To obtain an estimate of coronary blood flow, coronary-driving pressure (CDP) was calculated as the difference between DBP and LVEDP ${ }^{8}$.

MI was produced by ligature of the left coronary artery, by using a modification of a previously described technique $^{9}$. Sham-operated rats were operated on similarly except for not tying the ligature around the coronary artery.

During recovery, after observation of spontaneous respiration, mechanical ventilation was concluded and arterial catheters were withdrawn. The animals were returned to their individual cages.

Four weeks after the experiment, animals were anesthetized with Pentobarbital sodium, $30 \mathrm{mg} \cdot \mathrm{kg}^{-1}$ i.p. The heart, lungs, and liver were removed, cleaned, and weighed. Atria and large vessels were removed before weighing the heart. MI was demonstrated by grossly visible scarring of the LV free wall.

A coronal slice of the heart including both ventricles was obtained at the equatorial plane where the largest surface of infarction was detected. Tissue fixation was performed in 10 percent buffered formalin.

Six-micron paraffin embedded sections were cut and stained with Sirius Red 3BA in saturated picric acid solution ${ }^{10}$. By using an image analysis system (Leica Q500 iW, Leica Imaging Systems ltd., Cambridge, UK), these sections were analyzed morphometrically. Fibrillar collagen was identified in the picrosirius-stained sections by its red colored appearance.

A videocamera equipped with a macro lens permitting the visualization of the entire coronal section of each heart was used to identify MI and non-MI regions and to obtain infarct size. The ratios between endocardial infarct surface length and endocardial total LV circumference and the ratios between epicardial infarct surface length and epicardial total LV circumference were calculated and averaged to obtain infarct size ${ }^{2}$.

Using a microscopic $\mathrm{x} 10$ objective, fibrillar collagen within MI and non-MI was estimated as a collagen volume fraction (CVF, \%). CVF was determined as the percentage of red-stained connective tissue areas per total myocardial area, excluding perivascular collagen. Non-MI CVF was addressed separately in 3 distinct regions of each tissue section examined: the inner third of the non-MI corresponding to the LV subendocardium (SE), the medium third of the
non-MI interventricular septal wall (IVS), and the right ventricular myocardium(RV).

MI rats were classified into groups SMI and LMI, according to the presence of small $(\leq 30 \%)$ or large MI (>30\%), respectively.

ANOVA, complemented by the Bonferroni $t$ test, was used for comparing quantitative structural variables between MI groups and the sham group. Repeated-measures analysis of variance, complemented by the Wald test, was used to evaluate the effects of MI on hemodynamic variables. Normality and equal variance were verified in all analyses. Data were expressed as mean \pm S.E.M. Statistical significance was established at a $\mathrm{p}<0.05$.

The potential relationships between postexperiment hemodynamic variables and subsequent fibrosis deposition within non-MI was assessed by using Pearson's correlation coefficient. Multiple linear regression analysis was performed for detecting among the hemodynamic variables which were the best predictors for subsequent fibrosis deposition. The stepwise selection method was used, with p-values of 0.10 and 0.05 considered significant for entering a variable into or removing it from the model, respectively. The statistical analysis was performed with SAS (Statistical Analysis System) software ${ }^{11}$.

\section{Results}

The 3 study groups comprised 7 rats each. Infarct size was $20.4 \pm 1.5 \%$ (range: 15.1 to $25.3 \%$ ) in the SMI group and $50.5 \pm 2.4 \%$ (range: 40.8 to $58 \%$ ) in the LMI group.

Heart, lungs, and liver to body weight ratios were significantly greater in the LMI than in the sham group (table I).

Figure 1 illustrates the hemodynamic variables computed before and after the experiment. Before surgery, all 3 groups were statistically comparable. Surgery did not affect any of the hemodynamic variables in the sham group.

LVEDP increased fivefold in the LMI group, resulting in significantly higher values than in the sham group. The twofold increase in LVEDP observed in the SMI group was not statistically different from that in the sham group.

CDP significantly decreased only in the LMI group (-30\%). Postexperiment CDP was comparable among all 3 groups.

A statistically significant decrease in $\mathrm{LV} \mathrm{dP/dt}$ $(-36 \%)$ was demonstrated for the LMI group alone, and LV

\begin{tabular}{|lrrrr|}
\hline \multicolumn{5}{|c|}{$\begin{array}{l}\text { Table I - Body weight and organs to body weight ratios at } 4 \text { weeks of } \\
\text { follow-up in sham, SMI, and LMI groups. }\end{array}$} \\
\hline \multicolumn{7}{|c}{ sham } & \multicolumn{2}{c}{ SMI } & LMI & p-value \\
\hline BW (g) & $321.4 \pm 8.5$ & $325.6 \pm 5.9$ & $327.2 \pm 9.2$ & 0.71 \\
Heart / BW x 1000 & $3.3 \pm 0.1$ & $3.4 \pm 0.1$ & $4.6 \pm 0.3 *$ & 0.002 \\
Lung / BW x 1000 & $6.1 \pm 0.4$ & $6.5 \pm 0.8$ & $10.1 \pm 1.6^{*}$ & 0.03 \\
Liver / BW x 1000 & $33.5 \pm 1.4$ & $36 \pm 1.3$ & $43.3 \pm 3.7^{*}$ & 0.03 \\
\hline \multirow{2}{*}{ BW- indicates body weight; SMI- small myocardial infarction; LMI- large } \\
myocardial infarction; * p <0.05 vs. sham. \\
\hline
\end{tabular}




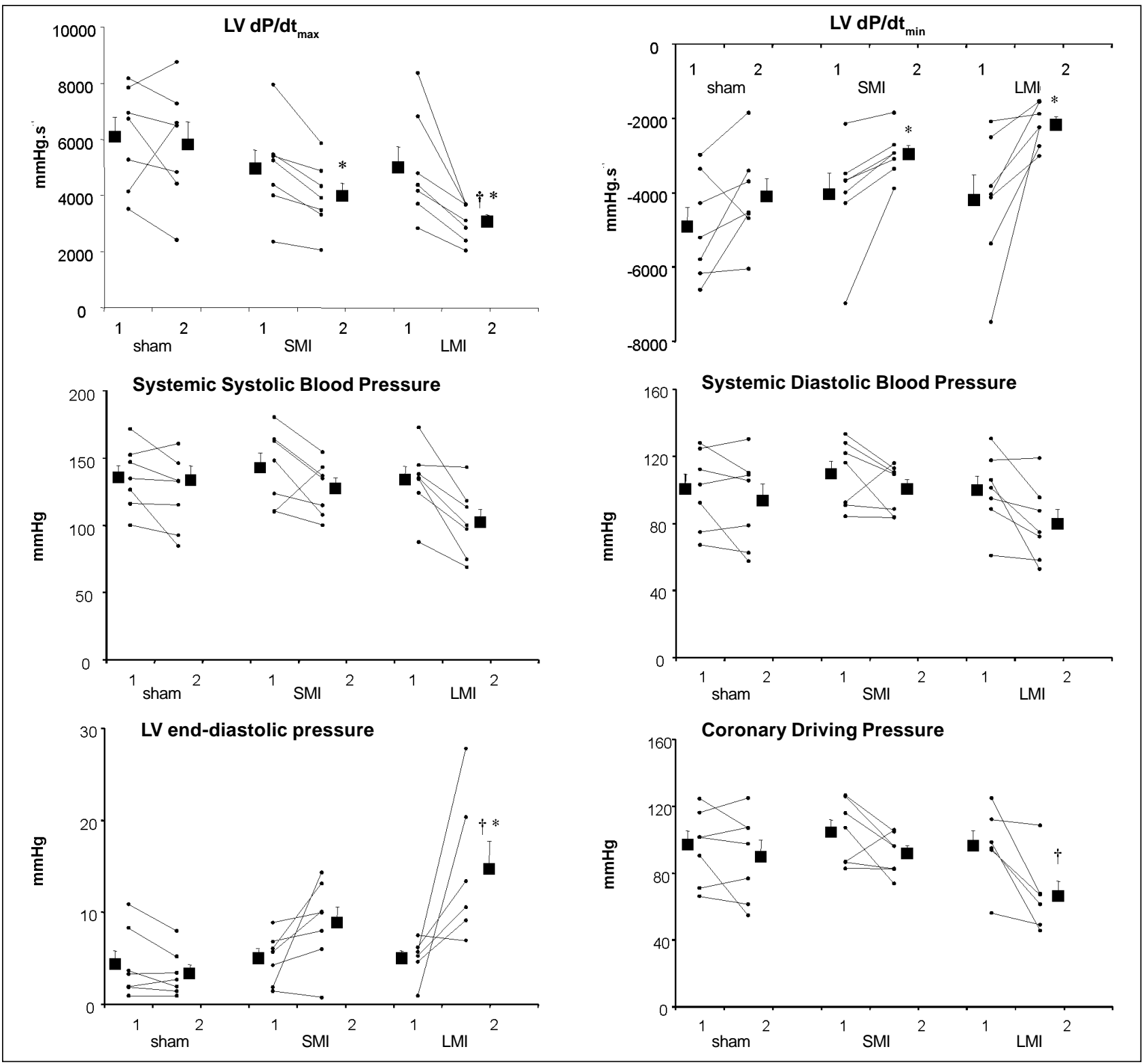

Fig. 1 - Systemic and left ventricular (LV) hemodynamic measurements of the sham, SMI, and LMI groups computed before (1) and following (2) the experiment. * $=$ p $<0.05$ vs. sham; $\dagger=\mathrm{p}<0.05,2$ to 1 difference in comparison with 2 to 1 difference found in sham.

$\mathrm{dP} / \mathrm{dt}_{\text {min }}$ did not change significantly. Despite these nonuniform and not always significant changes, after surgery LV $\mathrm{dP} / \mathrm{dt}_{\max }$ and $\mathrm{LV} \mathrm{dP/dt}{ }_{\text {min }}$ turned out to be statistically different between each the MI groups and the sham group.

SBP and DBP had a tendency to decrease, particularly in the LMI group $(-5 \%$ and $-7 \%,-9 \%$ and $-7 \%,-23 \%$ and $19 \%$ for sham, SMI, and LMI groups, respectively) but remained comparable among groups after surgery.

Surgery did not change heart rate in any group (sham, $345 \pm 17$ to $330 \pm 18$; SMI $323 \pm 16$ to $317 \pm 14$; LMI $353 \pm 14$ to $328 \pm 16$ beats. $\mathrm{min}^{-1}$ ).

Table II depicts CVF determined within MI and nonMI regions. MI CVF was comparable between the SMI and LMI groups. Non-MI CVF in IVS and in RV was comparable among the 3 groups. Otherwise, LMI showed a greater nonMI SE CVF than that in the sham group.
In figure 2, four heart tissue sections are depicted under progressive magnification representing an animal included in the LMI group. An evident increase can be

\begin{tabular}{|c|c|c|c|c|}
\hline \multicolumn{5}{|c|}{$\begin{array}{c}\text { Table II - Collagen volume fraction of sham, SMI, and LMI groups in } \\
\text { myocardial infarction and in } 3 \text { different noninfarcted myocardial } \\
\text { regions } 4 \text { weeks after surgical experiment }\end{array}$} \\
\hline $\operatorname{CVF}(\%)$ & sham & SMI & LMI & p-value \\
\hline Infarcted region & & $58.4 \pm 3.3$ & $52.8 \pm 2.5$ & 0.21 \\
\hline LV subendocardium & $1.7 \pm 0.4$ & $2.2 \pm 0.7$ & $5.6 \pm 1.2^{*}$ & 0.008 \\
\hline Interventricular septum & $0.7 \pm 0.1$ & $0.6 \pm 0.1$ & $0.5 \pm 0.1$ & 0.24 \\
\hline Right ventricle & $1 \pm 0.2$ & $1.3 \pm 0.2$ & $0.7 \pm 0.2$ & 0.12 \\
\hline
\end{tabular}



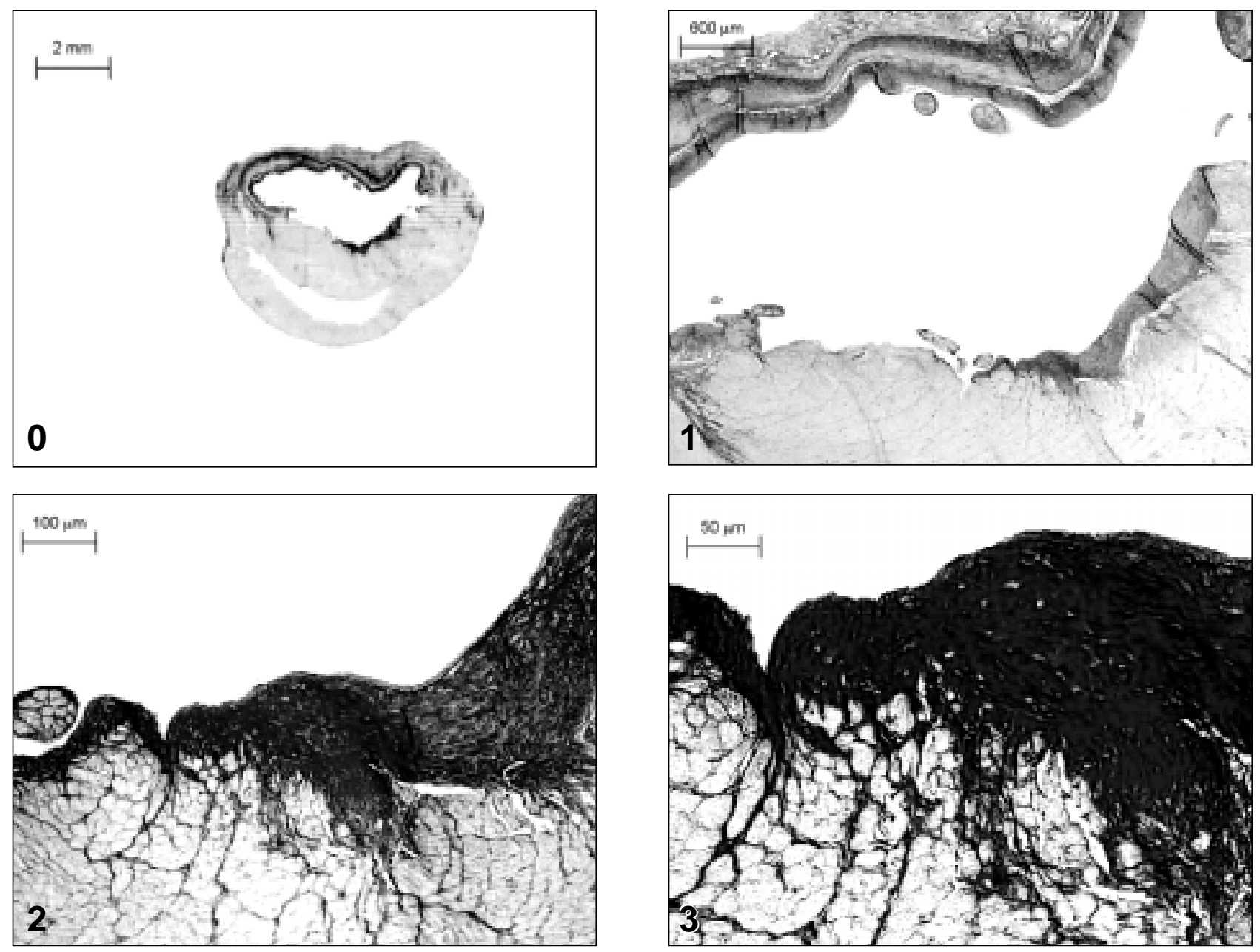

Fig. 2 - Picrosirius red-stained sections of a coronal heart tissue section from rat with a large myocardial infarction. The (0) represents a picture obtained under a macro lens and shows the entire tissue section encompassing both the left and the right ventricles. The subsequent panels represent endomyocardial layers obtained under progressive microscopic magnification: 1) corresponds to $2.5,2$ ) to $x 10$ and 3) x20 magnification objectives.

observed in collagen fibers revealed as a thick layer of fibrosis scattered within the non-MI SE LV.

As CVF was predominantly found within the SE layer of non-MI LV, the amount of collagen fibers found at this location was used for further statistical analyses. Of the hemodynamic variables investigated, non-MI SE CVF correlated inversely with $\operatorname{SBP}(\mathrm{r}=-0.51, \mathrm{p}=0.02), \mathrm{DBP}(\mathrm{r}=-0.44, \mathrm{p}=$ $0.04)$, and CDP $(r=-0.52, p=0.02)$, and directly with LV dP/ $\mathrm{dt}_{\text {min }}(\mathrm{r}=0.44, \mathrm{p}=0.04)$.

CDP was the only hemodynamic variable identified as independently related to non-MI SE CVF (parameter estimate $=-0.061$, standard error $=0.02$, Rsqr $=0.27, p=0.02$ ). Figure 3 graphically represents the linear correlation found between non-MISE, CVF, and CDP.

\section{Discussion}

The present study confirmed previous findings showing that experimental left coronary artery ligature in rats produces immediate systemic and LV hemodynamic changes ${ }^{12}$. These changes occurred predominantly in animals with the largest MI and corresponded to decreases in both
$\mathrm{LV} \mathrm{dP/dt}$ max and CDP and to increases in both LVEDP and LV $\mathrm{dP} / \mathrm{dt}_{\text {min }}$.

In particular, our findings allude to a relationship between acute post-MI CDP and fibrosis deposition within nonMI examined 4 weeks later. The increase in non-MI collagen

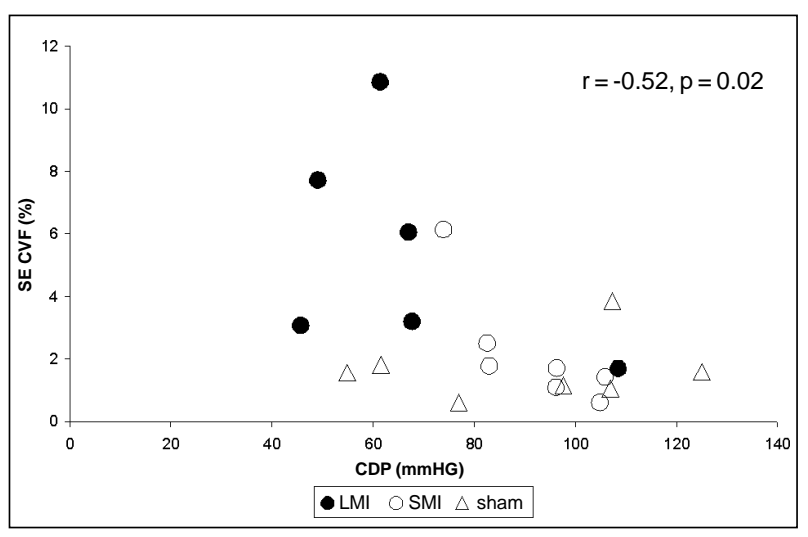

Fig. 3 - Relationship between subendocardial (SE) collagen volume fraction (CVF) in noninfarcted myocardium at 4 weeks and coronary driving pressure (CDP) measured immediately after the surgical experiment. 
content was found rather typically at the SE region. Recently, experiments using the isolated rat heart preparation have shown that baseline flow may be reduced by as much as $28 \%$ immediately after coronary artery ligature ${ }^{13}$.

The in vivo nature of the present study permitted us to establish a potential connection between acute hemodynamic changes jeopardizing blood flow to non-MI and late development of SE fibrosis.

As hemodynamics was more severely impaired in the LMI group, we speculate that the acute impairment of LV systolic performance ${ }^{2}$ chiefly contributed to the reduction in coronary perfusion pressure and blood flow ${ }^{8}$. Ventricular diastolic dysfunction would further limit coronary perfusion and aggravate ischemia.

We recognize that although CDP has been demonstrated to be an independent predictor of subsequent SE fibrosis, the associated r-square value was of not so great a magnitude. In part, this may be due to the relatively early hemodynamic measurements undertaken in the present study. Although studies performed in humans ${ }^{14}$ and in dogs ${ }^{15}$ suggest that an initial transitory improvement may occur in post-MI hemodynamics, in rats these parameters usually deteriorated during the first 24 hours ${ }^{12}$ and beyond ${ }^{16-19}$. Further ischemia at the SE region may occur during the progression of remodeling as a consequence of reduced coronary blood flow reserve ${ }^{20-22}$.

Controversy regarding the pathogenesis of collagen accumulation within non-MI, involving different local and systemic mediators ${ }^{3,4,23-26}$, still remains. The present findings indicate that underperfusion to non-MI should also be taken into account as a potential mechanism, particularly to explain SE collagen fiber accumulation.

The predominance of SE over interstitial fibrosis has been reported before ${ }^{27,28}$. This pattern of collagen deposi- tion is rather in support of being representative of a reparative scarring process in response to impeding myocardial perfusion. It may also explain reports of remote wall motion abnormalities occurring early on and persisting for as long as 2 months after MI $^{29,30}$.

Ventricular remodeling has been characterized by thinning and expansion of the infarcted wall, on the one hand, and by enlargement of the ventricular cavity, on the other, occurring as early as 2 days ${ }^{31}$ after MI, or even earlier ${ }^{29}$. It has been attributed to the occurrence of side to side slippage of remnant myocyte fibers ${ }^{32}$. In disagreement with this assumption is the fact that LV epicardial circumference length remains unchanged up to 21 days after $\mathrm{MI}^{31}$. Alternatively, it is quite conceivable to suppose that early enlargement of the ventricular cavity may be, in part, the result of loss of myocyte cells jeopardized by poor coronary perfusion taking place under unfavorable acute hemodynamic conditions, such as those reported in the present study.

Based on the present findings, we speculate that impeding ischemia of non-MI occurs acutely after MI, particularly affecting the SE region, and may result from hemodynamic changes interfering with CDP. This appears to play a chief role in subsequent fibrosis found in this region. To be confirmed, this hypothesis deserves further investigation.

\section{Acknowledgments}

We are grateful to Dr Maria de Lourdes Higuchi for her technical assistance and for providing the facilities for processing and analyzing the tissue sections. We also thank Dr Irineu Tadeu Velasco for providing the facilities of the experimental laboratory of the University of São Paulo Medical School(LIM-51) where this study was performed.

\section{References}

1. Anversa P, Li P, Zhang X, Olivetti G, Capasso JM. Ischaemic myocardial injury and ventricular remodelling. Cardiovasc Res 1993; 27: 145-57.

2. Pfeffer MA, Pfeffer JM, Fishbein MC, et al. Myocardial infarct size and ventricular function in rats. Circ Res 1979; 44: 503-12.

3. Frimm CC, Sun Y, Weber KT. Wound healing following myocardial infarction in the rat: role for bradykinin and prostaglandins. J Mol Cell Cardiol 1996; 28: 1279-85.

4. Nicoletti A, Michel JB. Cardiac fibrosis and inflammation: interaction with hemodynamic and hormonal factors. Cardiovasc Res 1999; 41: 532-43.

5. Walsh JT, Batin PD, Hawkins M, McEntegart D, Cowley AJ. Ventricular dilatation in the absence of ACE inhibitors: influence of haemodynamic and neurohormonal variables following myocardial infarction. Heart 1999; 81: 33-9.

6. Van Kerckhoven R, Kalkman EA, Saxena PR, Schoemaker RG. Altered cardiac collagen and associated changes in diastolic function of infarcted rat hearts. Cardiovasc Res 2000; 46: 316-23.

7. Marijianowski MM, Teeling P, Becker AE. Remodeling after myocardial infarction in humans is not associated with interstitial fibrosis of noninfarcted myocardium. J Am Coll Cardiol 1997; 30: 76-82.

8. Cross C, Riechen P, Salisbury P. Coronary driving pressure and vasomotor tonus as determinants of coronary blood flow. Circulation Research 1961; 9: 589-600.

9. Fishbein MC, Maclean D, Maroko PR. Experimental myocardial infarction in the rat: qualitative and quantitative changes during pathologic evolution. Am J Pathol 1978; 90: 57-70.
10. Junqueira LC, Bignolas G, Brentani RR. Picrosirius staining plus polarization microscopy, a specific method for collagen detection in tissue sections. Histochem J 1979; 11: 447-55.

11. SAS Institute Inc. SAS. SAS/STAT User's Guide. 6 ed. Cary, NC: SAS Institute, 1989.

12. Schoemaker RG, Urquhart J, Debets JJ, Struyker Boudier HA, Smits JF. Acute hemodynamic effects of coronary artery ligation in conscious rats. Basic Res Cardiol 1990; 85: 9-20.

13. Nelissen-Vrancken HJ, Debets JJ, Snoeckx LH, Daemen MJ,Smits JF. Time-related normalization of maximal coronary flow in isolated perfused hearts of rats with myocardial infarction. Circulation 1996; 93: 349-55.

14. Ginzton LE, Conant R, Rodrigues DM, Laks MM. Functional significance of hypertrophy of the noninfarcted myocardium after myocardial infarction in humans. Circulation 1989; 80: 816-22.

15. Gibbons EF, Hogan RD, Franklin TD, Nolting M, Weyman AE. The natural history of regional dysfunction in a canine preparation of chronic infarction. Circulation 1985; 71: 394-402.

16. Capasso JM, Li P, Zhang X, Anversa P. Heterogeneity of ventricular remodeling after acute myocardial infarction in rats. Am J Physiol 1992; 262(2 Pt 2): H486-95.

17. Hu K, Gaudron P, Schmidt TJ, Hoffmann KD, Ertl G. Aggravation of left ventricular remodeling by a novel specific endothelin ET(A) antagonist EMD94246 in rats with experimental myocardial infarction. J Cardiovasc Pharmacol 1998; 32: 505-8.

18. Mulder P, Devaux B, Richard V, et al. Early versus delayed angiotensin-conver- 
ting enzyme inhibition in experimental chronic heart failure: effects on survival, hemodynamics, and cardiovascular remodeling. Circulation 1997; 95: 1314-9.

19. Mulder P, Richard V, Derumeaux G, et al. Role of endogenous endothelin in chronic heart failure: effect of long-term treatment with an endothelin antagonist on survival, hemodynamics, and cardiac remodeling. Circulation 1997; 96: 1976-82.

20. Schoemaker RG, Saxena PR, Kalkman EA. Low-dose aspirin improves in vivo hemodynamics in conscious, chronically infarcted rats. Cardiovasc Res 1998; 37: 108-14.

21. Uren NG, Crake T, Lefroy DC, de Silva R, Davies GJ, Maseri A. Reduced coronary vasodilator function in infarcted and normal myocardium after myocardial infarction. N Engl J Med 1994; 331: 222-7.

22. Kalkman EA, Bilgin YM, van Haren P, van Suylen RJ, Saxena PR, Schoemaker RG. Determinants of coronary reserve in rats subjected to coronary artery ligation or aortic banding. Cardiovasc Res 1996; 32: 1088-95.

23. Frimm CC, Sun Y, Weber KT. Angiotensin II receptor blockade and myocardial fibrosis of the infarcted rat heart. J Lab Clin Med 1997; 129: 439-46.

24. Sun Y, Cleutjens JP, Diaz-Arias AA, Weber KT. Cardiac angiotensin converting enzyme and myocardial fibrosis in the rat. Cardiovasc Res 1994; 28: 1423-32.
25. Sun Y, Weber KT. Angiotensin II receptor binding following myocardial infarction in the rat. Cardiovasc Res 1994; 28: 1623-8.

26. Weber KT. Targeting pathological remodeling: concepts of cardioprotection and reparation. Circulation 2000; 102: 1342-5.

27. Beltrami CA, Finato N, Rocco M, et al. Structural basis of end-stage failure in ischemic cardiomyopathy in humans. Circulation 1994; 89: 151-63.

28. Michel JB, Lattion AL, Salzmann JL, et al. Hormonal and cardiac effects of converting enzyme inhibition in rat myocardial infarction. Circ Res 1988; 62: 641-50.

29. Solomon SD, Greaves SC, Rayan M, Finn P, Pfeffer MA, Pfeffer JM. Temporal dissociation of left ventricular function and remodeling following experimental myocardial infarction in rats. J Card Fail 1999; 5: 213-23.

30. Kramer CM, Lima JA, Reichek N, et al. Regional differences in function within noninfarcted myocardium during left ventricular remodeling. Circulation 1993; 88: $1279-88$.

31. Roberts CS, Maclean D, Maroko P, Kloner RA. Early and late remodeling of the left ventricle after acute myocardial infarction. Am J Cardiol 1984; 54: 407-10.

32. Olivetti G, Capasso JM, Sonnenblick EH, Anversa P. Side-to-side slippage of myocytes participates in ventricular wall remodeling acutely after myocardial infarction in rats. Circ Res 1990; 67: 23-34.

Bula resumida - MICARDIS ${ }^{\circledast}$ Telmisartam - Uso adulto - Forma farmacêutica e apresentações: Comprimidos de $40 \mathrm{mg}$ : embalagens com $14 \mathrm{e} 28$ comprimidos. Comprimidos de $80 \mathrm{mg}$ : embalagens com 14 e 28 comprimidos. Composição: Cada comprimido contém $40 \mathrm{mg}$ ou $80 \mathrm{mg}$ de telmisartam. Excipientes q.s.p. 1 comprimido. Indicações: Tratamento da hipertensão arterial, como monoterapia ou em associação com outros agentes anti-hipertensivos. Contra-indicações: Hipersensibilidade ao ingrediente ativo ou aos excipientes. Gravidez e lactação. Obstrução biliar. Disfunção hepática ou renal grave. Intolerância hereditária à frutose. Precauções: Hipertensão renovascular: pacientes com estenose arterial renal bilateral ou estenose da artéria com um único rim funcionando: risco aumentado de hipotensão grave e insuficiência renal. Disfunção renal ou transplante hepático: monitoração periódica dos níveis séricos de potássio e creatinina. Não há experiência em pacientes com transplante renal recente. Desidratação: hipotensão sintomática, especialmente após a primeira dose, pode ocorrer em pacientes que têm volemia e/ou sódio depletado, o que deve ser corrigido antes do início da terapêutica com MICARDIS. Outras condições de estimulação do SRAA e condiçôes dependentes da atividade SRAA (insuficiência cardiaca congestiva grave): hipotensão aguda, hiperazotemia, oligúria ou, raramente, insuficiência renal aguda. se monitoração adequada dos níveis séricos de potássio em pacientes de risco. Diuréticos poupadores de potássio, suplementos de potássio, sais de potássio ou outros medicamentos que podem aumentar os niveis de potássio, como a heparina: podem levar a um aumento da potassemia. Portanto, nestas situaçōes MICARDIS deve ser administrado com cautela. Distúrbios hepatobiliares: pode-se esperar redução da depuração em pacientes com disfunçōes obstrutivas do sistema biliar ou insuficiência hepática, pois a eliminação da droga é principalmente biliar. Intolerância à frutose: os comprimidos de MICARDIS contém sorbitol; portanto, é inadequado para pacientes com intolerância hereditária à frutose. Outros: menor eficácia na redução da pressão arterial na população negra do que na população não-negra. Cardiopatia isquêmica ou doença cardiovascular isquêmica pode resultar em infarto do miocárdio. Interações medicamentosas: MICARDIS pode aumentar o efeito hipotensor de outros agentes anti-hipertensivos. Observouse um aumento de $20 \%$ da concentração plasmática média de digoxina. Relataram-se aumentos reversiveis das concentraçōes séricas de litio e de toxicidade; portanto, recomenda-se cuidadosa monitoração
do uso concomitante com lítio. Gravidez e lactação: Contra-indicado. Reações adversas: As reações adversas à droga obtidas a partir de todos os estudos clínicos com telmisartam foram: Infecções do trato do uso concomitante com lítio. Gravidez e lactação: Contra-indicado. Reaçoes adversas: As reaçōes adversas à droga obtidas a partir de todos os estudos clinicos com telmisartam foram: Infecçōes do trato costas, cãibras nas pernas ou dores nas pernas, mialgia, sintomas de tendinite, dor no peito, sintomas de gripe. Além disso, desde a introdução de telmisartam no mercado, relataram-se casos raros de eritema, prurido, desmaio, insônia, depressão, vômito, hipotensão, bradicardia, taquicardia, dispnéia, eosinofilia, trombocitopenia, fraqueza e perda de eficácia. Relataram-se casos isolados de angioedema, urticária prurido, desmaio, insônia, depressão, vômito, hipotensão, bradicardia, taquicardia, dispnéia, eosinofilia, trombocitopenia, fraqueza e perda de eficácia. Relataram-se casos isolados de angioedema, urticária na habilidade de dirigir e utilizar máquinas: Ainda não se realizaram estudos específicos. Contudo, ao dirigir ou operar máquinas, pode ocasionalmente ocorrer tontura ou sonolência. Posologia: A dose recomendada é de $40 \mathrm{mg}$ uma vez ao dia. Alguns pacientes podem apresentar benefício com dose diária de $20 \mathrm{mg}$. Em casos em que a pressão arterial pretendida não seja atingida, a dose de MICARDIS pode ser aumentada para no máximo $80 \mathrm{mg}$ uma vez ao dia. Alternativamente, MICARDIS pode ser usado em combinação com diuréticos tiazídicos, como a hidroclorotiazida, para se obter uma redução maior da pressão arterial. Quando se considerar um aumento da dose, deve-se levar em conta que o máximo efeito anti-hipertensivo é geralmente atingido quatro a oito semanas apos o inicio do tratamento. MICARDIS pode ser administrado com ou sem alimento. Insuficiência renal: Não há necessidade de ajustes de dose em pacientes com insuficiência renal leve a moderada. Telmisartam não é removido do sangue por Crianças e adolescentes: Não há dados de segurança e eficácia de MICARDIS em crianças e adolescentes. VENDA SOB PRESCRIÇÃO MÉDICA - MS - 1.0367.0110 - Boehringer Ingelheim do Brasil Química e Farmacêutica Ltda.

Bula resumida - MICARDIS ${ }^{\oplus}$ HCT - Telmisartam/Hidroclorotiazida - Uso adulto - Composição: Cada comprimido de MICARDIS HCT contém $40 \mathrm{mg} / 12,5 \mathrm{mg}$ ou $80 \mathrm{mg} / 12,5 \mathrm{mg}$ de telmisartam/hidroclorotiazida. Embalagens com 14 e 28 comprimidos. Excipientes q.s.p. 1 comprimido. Indicações: Tratamento da hipertensão arterial. MICARDIS HCT, como associação de dose fixa, é indicado em pacientes cuja pressão arterial não é adequadamente controlada com telmisartam ou hidroclorotiazida isoladamente. Posologia: MICARDIS HCT deve ser administrado uma vez ao dia. A dose de MICARDIS pode ser aumentada gradativamente antes de substitui-lo pelo MICARDIS HCT. A substituição direta da monoterapia pelas combinaçoes fixas pode ser considerada. MICARDIS HCT 40/12,5 mg pode ser administrado em pacientes cujas pressoes sangüineas não sejam adequadamente controladas por MICARDIS $40 \mathrm{mg}$ ou hidroclorotiazida. MICARDIS HCT 80/12,5 mg pode ser administrado em pacientes cujas pressões arteriais não sejam adequadamente controladas por MICARDIS $80 \mathrm{mg}$ ou por MICARDIS HCT 40/12,5 mg. O máximo efeito anti-hipertensivo é obtido após 4 a 8 semanas de tratamento. Quando necessário, MICARDIS HCT pode ser disfunção renal grave. Nos casos leves a moderados, não se observaram efeitos adversos renais e não é necessário ajuste de dose. Recomenda-se monitoração periódica da função renal. Nos casos de disfunça r ne de dose con ou substâncias derivadas de sulfonamidas (como HCT). Gravidez e lactação Colestase e distúrbios obstrutivos biliares. Insuficiência hepática ou renal grave (depuração de creatinina 30 ml/min). excipientessemia refratária hiperalcemia. Precauções: Não utilizar nos casos de colestase, distúrbios biliares obstrutivos ou insuficiência hepática grave. Usar com cautela nos casos de função hepática Hipopotassemia refratária e hipercalcemia. Precauçoes: Náo utilizar nos casos de colestase, disturbios biliares obstrutivos ou insuficiência hepatica grave. Usar com cautela nos casos de função hepatica alterada ou doença hepática progressiva, pois pode ocorrer coma hepático. Há maior risco em pacientes com estenose arterial renal bilateral ou estenose com um único rim funcionando. Micardis HCT não deve recentemente. Recomenda-se a monitoração periódica dos níveis séricos de potássio, creatinina e ácido úrico. A azotemia associada a diuréticos tiazídicos pode ocorrer em pacientes com função renal alterada. Pode ocorrer hipotensão sintomática em pacientes que têm volemia e/ou sódio depletado. Insuficiência cardíaca congestiva grave ou doença renal, estenose da artéria renal tratada concomitantemente com drogas que afetem o sistema renina-angiotensina-aldosterona foram associados com hipotensão aguda, hiperazotemia, oligúria ou, raramente, insuficiência renal aguda. Aldosteronismo primário: não se recomenda o uso de telmisartam, precaução especial em estenose valvar aórtica ou mitral e cardiomiopatia hipertrófica obstrutiva. Como tiazidas podem prejudicar a tolerância à glicose, pode ser necessário ajuste no tratamento em diabéticos e pode ocorrer manifestação de diabetes latente. A hidroclorotiazida aumenta os níveis de colesterol e triglicérides; contudo, nenhum ou poucos efeitos adversos foram relatados na dose de $12,5 \mathrm{mg}$ contida em MICARDIS HCT. Pode ocorrer hiperuricemia ou precipitação de gota devido a hidroclorotiazida. Pode ser necessária monitoração periódica dos níveis séricos de eletrólitos, uma vez que a hidroclorotiazida pode causar desequilibrio eletrolítico ou de fluidos (hipopotassemia, hiponatremia e alcalose hipoclorêmica). O tratamento concomitante com telmisartam pode reduzir a hipopotassemia induzida por diuréticos, devido aos efeitos antagônicos. Diuréticos poupadores de potássio, suplementos de potássio ou substitutos do sal contendo potássio devem ser utilizados concomitantemente com cautela. Não há evidências de que MICARDIS HCT reduza ou previna hiponatremia induzida por diuréticos. A deficiência de cloreto é geralmente leve. Tiazidas podem causar elevação dos níveis séricos de cálcio e magnésio. Interromper o uso antes dos testes de função da paratireóide. Não utilizar em intolerância hereditária à frutose. A redução excessiva da pressão arterial no caso de doença
cardiovascular isquêmica pode ser prejudicial. Relatou-se exacerbação ou ativaçâo do lupus eritematoso sistêmico com o uso de hidroclorotiazida. Recomenda-se cautela no uso de anti-hipertensivos ao dirigir cardiovascular isquêmica pode ser prejudicial. Relatou-se exacerbação ou ativação do lupus eritematoso sistêmico com o uso de hidroclorotiazida. Recomenda-se cautela no uso de anti-hipertensivos ao dirigir e operar máquinas. Interações medicamentosas: Relataram-se aumentos reversíveis das concentraçōes séricas de lítio durante administração concomitante com inibidores da enzima conversora de angiotensina. Relataram-se casos de interação com antagonistas dos receptores da angiotensina Il. O risco de toxicidade por lítio pode ser aumentado com o uso de MICARDIS HCT. Recomenda-se a monitoração
dos níveis séricos de lítio durante o uso concomitante. O efeito de depleção de potássio da hidroclorotiazida é atenuado pelo efeito poupador de potássio do telmisartam, mas é potencializado por outros diuréticos dos níveis séricos de lítio durante o uso concomitante. O efeito de depleção de potássio da hidroclorotiazida é atenuado pelo efeito poupador de potássio do telmisartam, mas é potencializado por outros diuréticos
caliuréticos, laxantes, corticosteróides, ACTH, anfotericina, carbenoxolona, penicilina G sódica, ácido salicílico e derivados. Por outro lado, o uso concomitante de diuréticos poupadores de potássio, caliureticos, laxantes, corticosteroides, ACTH, antotericina, carbenoxolona, penicilina G sodica, ácido salicilico e derivados. Por outro lado, o uso concomitante de diuréticos poupadores de potássio, periódica de potássio na administração de MICARDIS HCT com digitálicos, antiarrítmicos e drogas que são conhecidamente indutoras de torsades de pointes. Telmisartam pode aumentar o efeito hipotensor de outros agentes anti-hipertensivos. Observou-se um aumento de $20 \%$ da concentração plasmática média de digoxina. Não se identificaram outras interações de importância clínica. Interações com a outros agentes anti-hipertensivos. Observou-se um aumento de $20 \%$ da concentração plasmática média de digoxina. Não se identificaram outras interaçōes de importância clínica. Interaçōes com a
hidroclorotiazida: álcool, barbitúricos ou narcóticos (potencialização da hipotensão ortostática); drogas antidiabéticas (ajustes de dose podem ser necessários); mettormina (risco de acidose láctica); colestiramina e resina colestipol (absorção de hidroclorotiazida é prejudicada); corticosteróides, ACTH (depleção eletrolítica, principalmente aumento de hipopotassemia); glicosídeos digitálicos (hipopotassemia ou hipomagnesemia induzida por tiazídicos favorece o aparecimento de arritmias cardíacas induzidas por digitálicos); drogas antiinflamatórias não-esteroidais (a administração de droga antiinflamatória não-esteroidal pode reduzir o efeito diurético, natriurético e anti-hipertensivo dos diuréticos tiazídicos em alguns pacientes). Os efeitos das aminas hipertensoras podem ser levemente diminuídos. Os relaxantes musculares esqueléticos não-despolarizantes são potencializados pela hidroclorotiazida. Medicamentos uricosúricos podem requerer ajustes. Verificou-se aumento da incidência de reaçōes de hipersensibilidade ao alopurinol. Os efeitos hiperglicêmicos dos beta-bloqueadores e diazóxido podem ser aumentados pelas tiazidas. Os agentes anticolinérgicos (por exemplo, atropina, biperideno) podem aumentar a biodisponibilidade das tiazidas. As tiazidas podem aumentar os eventos adversos da amantadina. As tiazidas podem reduzir a excreção renal de drogas citotóxicas (por exemplo, ciclofosfamida, metotrexato). Gravidez e lactação: É contra-indicado. Se ocorrer gravidez, telmisartam deve ser descontinuado o mais breve possível. As tiazidas atravessam a barreira placentária e podem causar distúrbios eletrolíticos no feto e é possível que ocorram outras reações. Relataram-se casos de trombocitopenia ou icterícia neonatal com o tratamento tiazídico materno. Tiazidas são excretadas no leite humano e podem inibir a lactação. Reações adversas: Foram relatadas as seguintes reações adversas: Bronquite, faringite, sinusite, infecçōes do trato respiratório superior, infecções do trato urinário, sialadenite, eosinofilia, anemia aplástica, anemia hemolítica, depressão da medula óssea, leucopenia, neutropenia/agranulocitose, trombocitopenia, alergia, reações anafiláticas, perda do controle da diabete, inquietação hipotensão postural, angiite necrotizante (vasculite), dispnéia, sofrimento respiratório (incluindo pneumonite e edema pulmonar), dor abdominal, diarréia, dispepsia, gastrite, dor de estômago, boca seca, flatulência, vômito, constipação, pancreatite, icterícia (icterícia hepatocelular ou colestática), eczema, aumento do suor, eritema, prurido, reações cutâneas do tipo lupus eritematoso, vasculite cutânea, reações de fotossensibilidade, erupções cutâneas, reativação do lupus eritematoso cutâneo, necrólise epidérmica tóxica, atralgia, artrose, dor nas costas, dor nas pernas, mialgia, cãibras nas pernas, sintomas de tendinite, fraqueza, espasmo muscular, nefrite intersticial, disfunção renal, glicosúria, impotência, sintomas de gripe, dor, dor no peito, perda da eficácia, febre. Investigaçōes: Diminuição da hemoglobina, aumento do ácido úrico, aumento na creatinina, aumento das enzimas hepáticas, aumento dos triglicérides. Assim como ocorre com outros antagonistas da angiotensina II, relataram-se casos isolados de angioedema,
urticária e outras reaçōes relacionadas. VENDA SOB PRESCRIÇÃO MÉDICA. - MS 1.0367.0134 Boehringer Ingelheim do Brasil Química e Farmacêutica Ltda. 